\title{
One American reflects on cigarette promotions in Poland in the 1990s
}

\author{
Scott Thompson \\ Sacramento, California
}

ADDRESS FOR CORRESPONDENCE: Scott Thompson, e-mail: ScottThompsonInSacto@gmail.com

\section{INTRODUCTION}

When the Berlin Wall fell in 1989 waves of Western influence immediately poured eastward, carrying everything from English teachers to grain elevators. Most visible in the flood were consumer products in colourful packaging, promoted with aspirational advertising.

The era of Coca-Cola, McDonald's, and Marlboro delighted millions of new consumers in Poland, but also set the stage for public health outcomes already plaguing some advanced consumer economies. Of these threats, none was more severe than the promotion of tobacco addiction.

\section{WORSE THAN THE MAFIA}

For generations, the Mafia's "code of honour" protected women and children in Sicily, New York, and beyond. Then the lure of huge profits from drug trafficking led gangsters to abandon their "morals" in favour of ruthless greed [1].

As drug traffickers from the start, multinational tobacco companies made no pretence of honour. On the contrary, they specifically targeted women and children for market growth, given that the majority of adult males in Poland were already smokers in 1990 . Was there any other explanation for obscene marketing gimmicks such as "Camel Fashion" shows in Warsaw or the nationwide "Marlboro Rock" concert series?

\section{PROTECTING AMERICAN, NOT POLISH, KIDS}

The American firms behind these shameless efforts to attract new Polish smokers pursued profits abroad partly because they were under attack at home. In the 1990s, US leaders spoke frequently about the need to "protect our children from the dangers of tobacco" [2]. Unfortunately, President Clinton expressed no such concern for the more than 96 per cent of children who did not live in the USA. Nor did any US embassy echo his criti- cism of tobacco marketing. Instead, they insisted that, as legal entities selling legal products, cigarette companies deserved the same support afforded all other businesses by the diplomatic mission. And so it was.

The US Embassy in Warsaw helped to promote Camel cigarettes, for example, by placing a branded ashtray canister outside one of its doors. This was removed only after the ambassador was informed that RJ Reynolds had sold its international operations to Japan Tobacco. The coincidence of Clinton denouncing Camel advertising at home while his representatives abroad made it look like the official brand of the US Government, despite the fact that it had become Japanese, epitomised the challenges to tobacco control progress in Poland.

\section{ARROGANCE IN GOD'S PLAYGROUND}

Summing up a millennium of tumult in staunchly Catholic Poland, a respected historian chose the title "God's Playground" for his 1979 book. A decade later, advertising experts from the West moved in and began to play on the faith many Poles now vested in all things American.

Most arrogant of all the marketeers were the tobacco pushers. These wealthy corporations from wealthy countries were promoting addictive, deadly products to poor people in a poor country already suffering from health disparities. And they relished their work, as revealed in a bizarre 1999 magazine ad showing a dozen frolicking Philip Morris staffers.

\section{PRIDE GOETH BEFORE A FALL}

As an American in Poland throughout the 1990s, I was mortified by the behaviour of tobacco companies from my country, and appalled by others promoting pseudo-American brands. Many used imagery from the beaches of my home state, California, where I knew smoking to be, in fact, very rare. They promoted addiction with phrases like "Discover the Taste of Freedom!", 


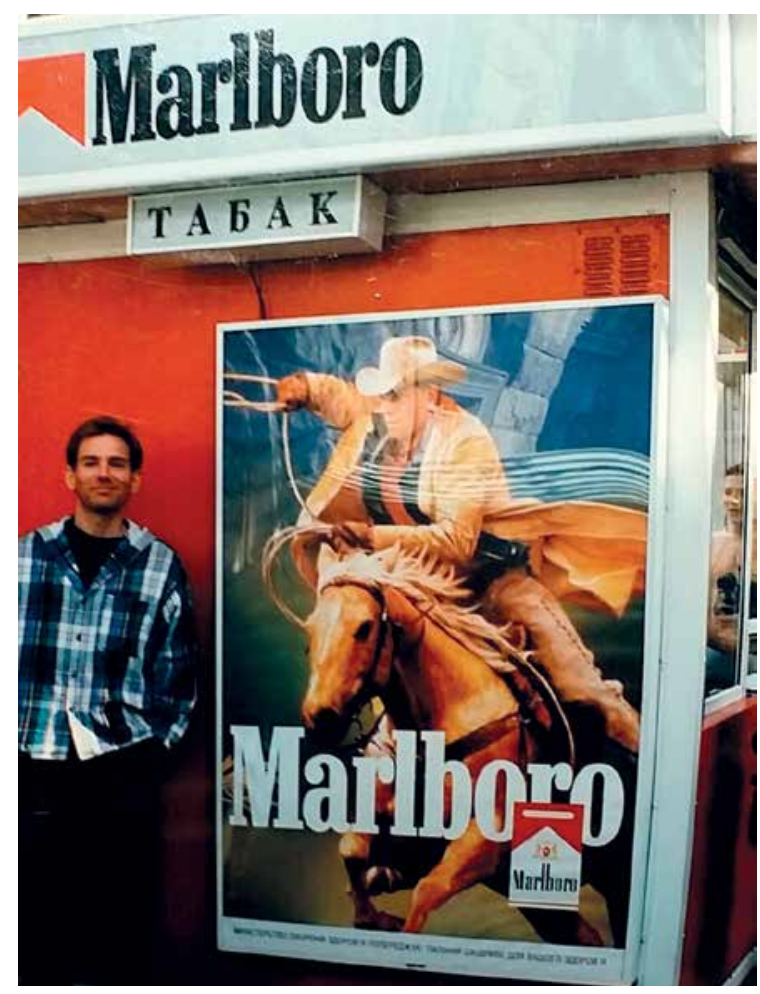

FIG. 1. To stop the tobacco epidemic, you must be willing to stand in the way of rampaging profiteers (Kiev, 1999)

assuming their target audience would miss the glaring irony. But they were wrong.

The companies saw Poland as fertile ground for flourishing sales to naïve new customers, a safe distance from regulatory efforts back home. But they miscalculated.

Due to extraordinary efforts described elsewhere in this journal, Poland did not become the El Dorado tobacco multinationals had envisioned. It became instead an exemplar of effective tobacco control.

\section{DISCLOSURE}

Author reports no conflict of interest.

\section{References}

1. UPI.com. Ex-mobster says drugs destroyed Mafia 'code of honor' Available from: http://www.upi.com/Archives/1988/04/12/Exmobster-says-drugs-destroyed-Mafia-code-of-honor/4307576820 800/ (accessed 1 November 2016).

2. CNN's AllPolitics. President Bill Clinton On Tobacco Legislation. Available from: http://www.cnn.com/ALLPOLITICS/1998/04/20/ clinton.tobacco/transcript.html (accessed 01 November 2016). 